\title{
Article \\ Manganese Is a Strong Specific Activator of the RNA Synthetic Activity of Human Poln
}

\author{
Eva Balint (D) and Ildiko Unk *(D)
}

check for updates

Citation: Balint, E.; Unk, I. Manganese Is a Strong Specific Activator of the RNA Synthetic Activity of Human Poln. Int. J. Mol. Sci. 2022, 23, 230. https://doi.org/ $10.3390 /$ ijms 23010230

Academic Editor: Antonio Mas López

Received: 1 December 2021

Accepted: 23 December 2021

Published: 26 December 2021

Publisher's Note: MDPI stays neutral with regard to jurisdictional claims in published maps and institutional affiliations.

Copyright: (C) 2021 by the authors. Licensee MDPI, Basel, Switzerland. This article is an open access article distributed under the terms and conditions of the Creative Commons Attribution (CC BY) license (https:// creativecommons.org/licenses/by/ $4.0 /)$.
Biological Research Centre, Institute of Genetics, Eotvos Loránd Research Network, H-6726 Szeged, Hungary; balint.eva@brc.hu

* Correspondence: unk.ildiko@brc.hu

Abstract: DNA polymerase $\eta$ (Pol $\eta$ ) is a translesion synthesis polymerase that can bypass different DNA lesions with varying efficiency and fidelity. Its most well-known function is the error-free bypass of ultraviolet light-induced cyclobutane pyrimidine dimers. The lack of this unique ability in humans leads to the development of a cancer-predisposing disease, the variant form of xeroderma pigmentosum. Human Poln can insert rNTPs during DNA synthesis, though with much lower efficiency than dNTPs, and it can even extend an RNA chain with ribonucleotides. We have previously shown that $\mathrm{Mn}^{2+}$ is a specific activator of the RNA synthetic activity of yeast Poln that increases the efficiency of the reaction by several thousand-fold over $\mathrm{Mg}^{2+}$. In this study, our goal was to investigate the metal cofactor dependence of RNA synthesis by human Poln. We found that out of the investigated metal cations, only $\mathrm{Mn}^{2+}$ supported robust RNA synthesis. Steady state kinetic analysis showed that $\mathrm{Mn}^{2+}$ activated the reaction a thousand-fold compared to $\mathrm{Mg}^{2+}$, even during DNA damage bypass opposite 8-oxoG and TT dimer. Our results revealed a two order of magnitude higher affinity of human Pol $\eta$ towards ribonucleotides in the presence of $\mathrm{Mn}^{2+}$ compared to $\mathrm{Mg}^{2+}$. It is noteworthy that activation occurred without lowering the base selectivity of the enzyme on undamaged templates, whereas the fidelity decreased across a TT dimer. In summary, our data strongly suggest that, like with its yeast homolog, $\mathrm{Mn}^{2+}$ is the proper metal cofactor of hPoln during RNA chain extension, and selective metal cofactor utilization contributes to switching between its DNA and RNA synthetic activities.

Keywords: human polymerase $\eta$; RNA extension; manganese; translesion synthesis; enzyme kinetics

\section{Introduction}

The intra- and extracellular environment produce agents that can be harmful to cells inheriting DNA molecules via introducing strand breaks or chemical linkage between adjacent bases or modifying the sugar or the base components of their DNA. Alteration or damage in DNA can potentially stall replication due to the high selectivity of the replicative DNA polymerase. Stalled replication can lead to DNA strand breaks, genomic rearrangements, and finally to cell death. To circumvent such fatal consequences, cells have evolved different DNA damage tolerance mechanisms that can ensure the continuity of replication without removing the damage. One of those mechanisms is direct synthesis across the damage site by translesion synthesis (TLS) DNA polymerases. The Y family of polymerases consists of TLS DNA polymerases capable of synthesizing across DNA damage with relatively high efficiency [1,2]. They can do so because their active center is more spacious and less selective than classical DNA polymerases enabling them to accommodate modified nucleosides. However, their low selectivity renders TLS polymerases error-prone, often inserting incorrect nucleotides opposite DNA lesions. As a result, TLS is often mutagenic and contributes to cancer development [3,4]. The complexity of the roles of TLS polymerases is highlighted by the fact that their inactivity or absence can also advance cancer formation [5-8]. Human DNA polymerase $\eta$ (hPol $\eta$ ) is a TLS polymerase with the unique ability to efficiently and without error bypass cyclobutane pyrimidine dimers 
(CPDs), one of the most frequent UV-induced DNA lesions [9,10]. Inactivity of hPoln leads to the development of xeroderma pigmentosum variant $(\mathrm{XP}-\mathrm{V})$ form that predisposes ultraviolet light (UV)-exposed individuals to cancer due to error-prone bypass of CPDs by other TLS polymerases. The other cognate DNA lesion of hPoln that it can bypass efficiently and largely without error is 7,8-dihydro-8-oxo-2-deoxyguanosine triphosphate (8-oxoG), one of the most prevalent oxidative lesions, but hPoln can also bypass a wide range of DNA lesions with varying fidelity [11-16].

hPoln, like most other DNA polymerases, can misinsert ribonucleosides (rNMPs) during DNA synthesis, contributing to the accumulation of rNMPs in the genome, although with a thousand-fold lower efficiency than dNMPs [17-20]. Embedded rNMPs represent probably the most abundant DNA lesions in the genome of eukaryotic cells but are efficiently removed by $\mathrm{RNase} \mathrm{H} 2$-dependent ribonucleotide excision repair [21-23]. The role and consequences of rNMPs in DNA are still debated, but their detrimental effect could contribute to the development of Aicardi-Goutières Syndrome and Systemic Lupus Erythematosus, both linked to mutated RNase H2 [24,25]. hPoln can insert rNMPs opposite DNA lesions as well $[18,20]$. Experiments using XP-V cell extracts indicated that hPoln was the key source of rCMP incorporation across cisplatin intrastrand guanine crosslinks [20]. In addition, hPol $\eta$ can extend RNA primers with rNTPs and shows a reverse transcriptase activity as it is able to synthesize DNA using RNA templates even opposite an 8-oxo-rG lesion, with comparable efficiency to using DNA templates [26,27]. Based on the latter two activities, it was suggested that hPoln participates in DNA damage bypass during RNA primer synthesis on the lagging strand during Okazaki fragment replication, and in double-strand break repair where it seals the gap using a transcript RNA as template [26].

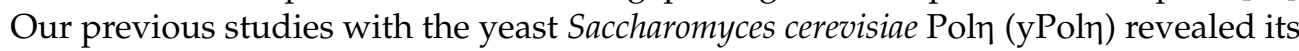
unexpected involvement in transcription [28]. We demonstrated that the lack of yPoln caused defects in transcription, particularly in transcription elongation in yeast cells. Moreover, we showed that yPoln could extend RNA primers using rNTPs on both undamaged templates and opposite TT dimer and 8-oxoG DNA lesions. Importantly, we found that the weak efficiency of RNA synthesis observed in the presence of the metal cofactor $\mathrm{Mg}^{2+}$ was enhanced several thousand-fold using $\mathrm{Mn}^{2+}$ without lowering the base selectivity of the enzyme on undamaged templates, as well as during DNA lesion bypass [29]. Other metal cations, however, did not support RNA synthesis by yPoln. Together, these results strongly suggested that $\mathrm{Mn}^{2+}$ was a specific activator of the RNA synthetic and translesion RNA synthetic activities of yPoln, and the enzyme utilized different metal cations to promote its DNA or RNA synthetic activities.

In this study, we investigated whether the weak RNA synthetic activity of hPoln could be improved by applying different metal cofactors in the reactions. Our results show that $\mathrm{Mn}^{2+}$ greatly enhances RNA extension by $\mathrm{hPol}$ compared with $\mathrm{Mg}^{2+}$ without decreasing the base selectivity of the polymerase. Activity increase could be observed opposite TT dimer and 8-oxoG DNA lesions as well. Our results suggest that, as with its yeast counterpart, $\mathrm{Mn}^{2+}$ is a specific activator of the RNA synthetic and translesion RNA synthetic activities of hPoln. We discuss the possible biological significance of the greatly improved RNA synthetic activity.

\section{Results}

\subsection{Metal Cation Dependency of the RNA Extension by hPol $\eta$}

The RNA extension ability of hPoln was tested using seven different metal cations at low, $0.5 \mathrm{mM}$, and at high, $5 \mathrm{mM}$, concentrations in in vitro primer extension reactions containing a DNA template, an RNA primer, and all four nucleotides at equal concentrations. The gel picture in Figure 1A shows that all tested cations supported synthesis to varying degrees using dNTPs, but $\mathrm{Mg}^{2+}$ and $\mathrm{Mn}^{2+}$ were the most effective, resulting in the extension of almost all of the added RNA primers. In contrast, $\mathrm{Ni}^{2+}$ and $\mathrm{Zn}^{2+}$ were the least effective. Importantly, using rNTPs, only $\mathrm{Mn}^{2+}$ catalyzed robust synthesis, even at low concentration, whereas $\mathrm{Mg}^{2+}$ was a weak activator but only at high concentration. 
The other metal cations did not support the reaction. These results suggested $\mathrm{Mn}^{2+}$ as the metal cofactor for hPol $\eta$ during RNA synthesis and $\mathrm{Mg}^{2+}$ as a weak substitution. Before characterizing RNA synthesis using the two cations, first, we determined the optimal concentration of $\mathrm{Mg}^{2+}$ and $\mathrm{Mn}^{2+}$ in the reactions. As Figure 1B shows, both ions catalyzed RNA extension at a wide range of concentrations, with the highest activities detected using $3-5 \mathrm{mM}$ of either metal ions, therefore we applied $4 \mathrm{mM}$ of each in the primer extension assays during this study.

A
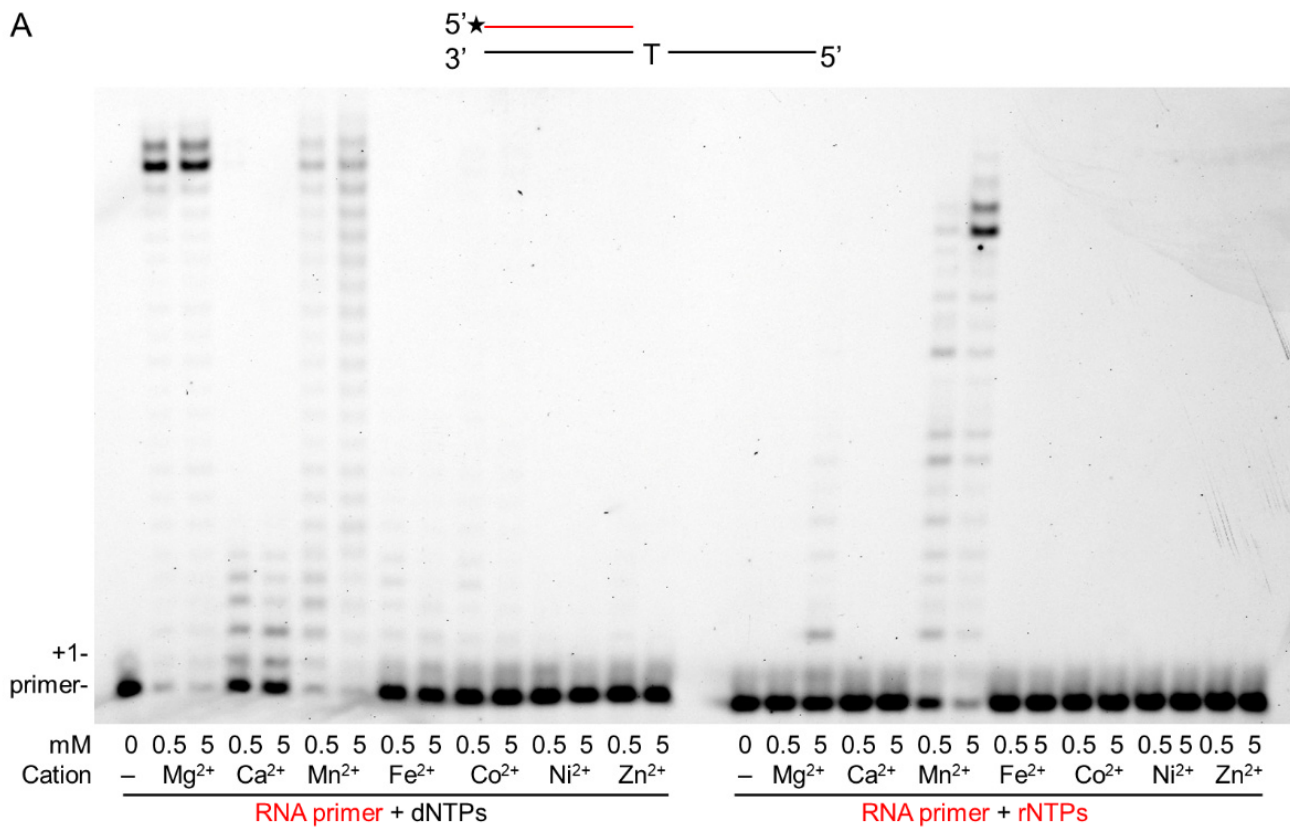

B

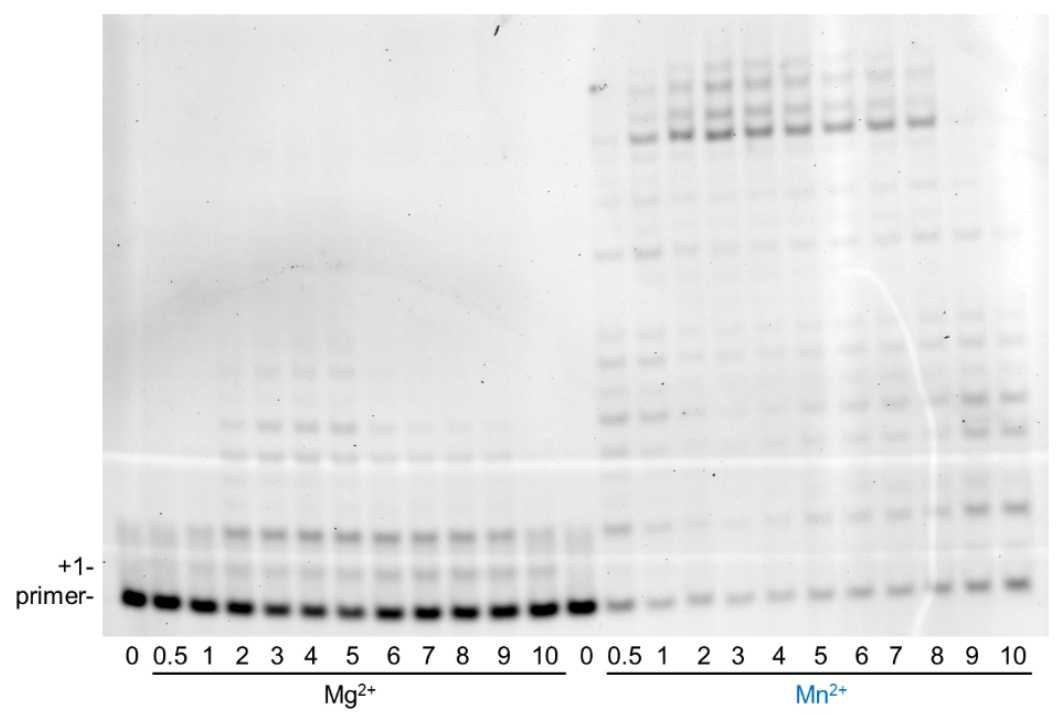

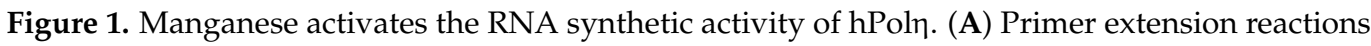
were performed applying two different concentrations of the indicated divalent cations. The structure of the primer/template used in the experiments is shown on the top. The black line depicts a DNA strand, and the red line is an RNA strand. The asterisk indicates a fluorescent label. The first templating nucleotide is shown. Reactions contained $30 \mathrm{nM}$ Poln, $20 \mathrm{nM}$ primer/template, and either $50 \mu \mathrm{M}$ of dNTPs (left panel) or $1 \mathrm{mM}$ of rNTPs (right panel). The positions of the primer and its one nucleotide extension are indicated. (B) $\mathrm{Mg}^{2+}$ and $\mathrm{Mn}^{2+}$ concentration-dependent RNA extension. Reactions were performed for $10 \mathrm{~min}$ with $20 \mathrm{nM} \mathrm{hPol} \eta$ in the presence of $20 \mathrm{nM}$ RNA/DNA and $1 \mathrm{mM}$ rNTPs. The concentrations of $\mathrm{Mn}^{2+}$ and $\mathrm{Mg}^{2+}$ are indicated below each lane. 


\subsection{Manganese Is a Specific Activator of hPoly during RNA Extension}

The effects of $\mathrm{Mg}^{2+}$ and $\mathrm{Mn}^{2+}$ on RNA synthesis by hPoln were investigated by first checking whether the two metal ions conferred distinct affinities to hPoln toward the primer/template. We applied DNA/DNA and RNA/DNA primer/templates in elec-

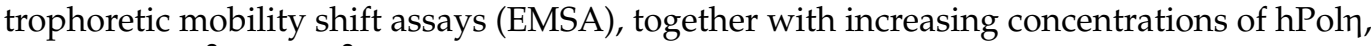
and with $\mathrm{Mg}^{2+}$ or $\mathrm{Mn}^{2+}$ in the reactions. The results of these experiments demonstrated that $\mathrm{hPol \eta}$ could bind the primer/templates in the presence of both $\mathrm{Mg}^{2+}$ and $\mathrm{Mn}^{2+}$, but the binding was slightly stronger with $\mathrm{Mn}^{2+}$ (Figure 2A,B). Fitting the quantitated data to the Hill equation revealed the Hill coefficients, which were $2.0 \pm 0.2,1.8 \pm 0.21 .9 \pm 0.5$, and $1.8 \pm 0.3$ for DNA primer with $\mathrm{Mg}^{2+}$, DNA primer with $\mathrm{Mn}^{2+}$, RNA primer with $\mathrm{Mg}^{2+}$, and RNA primer with $\mathrm{Mn}^{2+}$, respectively, indicating that $2 \mathrm{hPoln}$ molecules bound to a single substrate molecule in each case. In reactions with $\mathrm{Mg}^{2+}$, hPoln bound the DNA/DNA and RNA/DNA primer/template with similar affinities, with dissociation constants $\left(\mathrm{K}_{\mathrm{d}}\right)$ $\sim 60 \mathrm{nM} . \mathrm{Mn}^{2+}$ conferred almost the same affinity toward RNA/DNA $\left(\mathrm{K}_{\mathrm{d}} \sim 55 \mathrm{nM}\right)$ and a somewhat stronger affinity toward DNA/DNA $(\sim 40 \mathrm{nM})$, indicating that oligonucleotide binding did not contribute to the RNA extension enhancement observed with $\mathrm{Mn}^{2+}$.

A

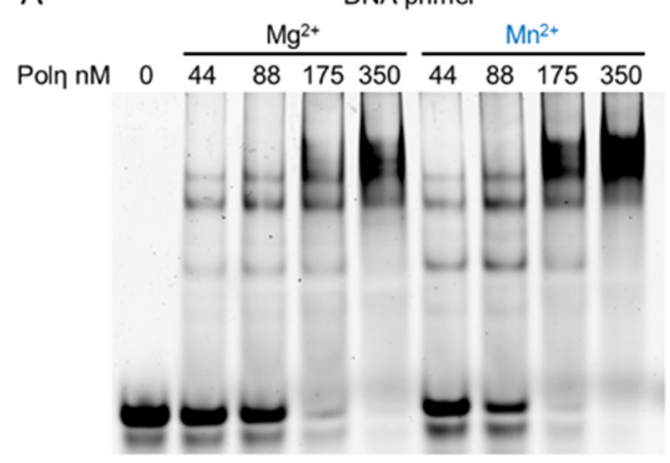

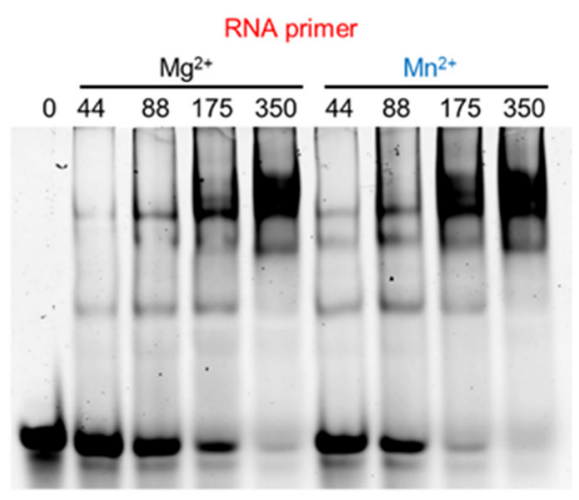

Figure 2. The binding affinity of hPol $\eta$ to DNA and RNA primers in the presence of $\mathrm{Mg}^{2+}$ or $\mathrm{Mn}^{2+}$. (A) DNA/DNA and RNA/DNA primer/templates $(20 \mathrm{nM})$ were incubated with 0 to $350 \mathrm{nM} \mathrm{hPol \eta}$ as indicated, in the presence of $4 \mathrm{mM} \mathrm{Mg}^{2+}$ or $\mathrm{Mn}^{2+}$. Complexes were resolved on a $4 \%$ non-denaturing polyacrylamide gel. (B) Quantitation of binding affinities. $10 \mathrm{nM}$ of DNA/DNA or RNA/DNA was incubated with hPoln (from 22 to $175 \mathrm{nM}$ in 11 increments). The standard deviation (SD) for each substrate is indicated.

In the next step, we assessed the velocity of RNA extension using the two cations. hPoln was incubated with $500 \mu \mathrm{M}$ of each rNTPs separately for increasing times. As Figure 3 shows, RNA extension was faster with $\mathrm{Mn}^{2+}$ than with $\mathrm{Mg}^{2+}$, although the difference was only a few folds. Next, we examined the effect of the metal cofactors on the affinity of the enzyme to ribonucleotides. Primer extension was carried out with increasing concentrations of the single incoming nucleotide. The representative gel pictures in Figure 4 show that hPoln had a much higher affinity to rNTPs when $\mathrm{Mn}^{2+}$ was applied as the metal cofactor. To get a more unequivocal picture, we determined the kinetic parameters of the extension by steady-state kinetic analysis. These experiments confirmed that the catalytic constants $\left(\mathrm{k}_{\mathrm{cat}}\right)$ indicating the velocity of rNMP insertion were almost the same with either $\mathrm{Mg}^{2+}$ or $\mathrm{Mn}^{2+}$, since the highest increase, observed during UMP insertion, was less than three-fold, in good agreement with the data presented above (Table 1). In contrast, the Michaelis-Menten constants $\left(\mathrm{K}_{\mathrm{m}}\right)$ showing the affinity of the enzyme to the substrate were several hundred-fold lower in the presence of $\mathrm{Mn}^{2+}$, reflecting a higher affinity of hPoln to rNTPs. Together these changes resulted in a 428-fold efficiency increase with the correct rCTP, a 774-fold in the case of the correct UTP, and a 1260-fold increase with the correct incoming rGTP. We note, however, that we could not compare rAMP insertion in the presence of the two metals, because $\mathrm{Mg}^{2+}$ facilitated the insertion of a dATP contamination 
in $\mathrm{rATP}$, as indicated by the appearance of a faster mobility band below the position of +1 extension (Figures 3 and 4).
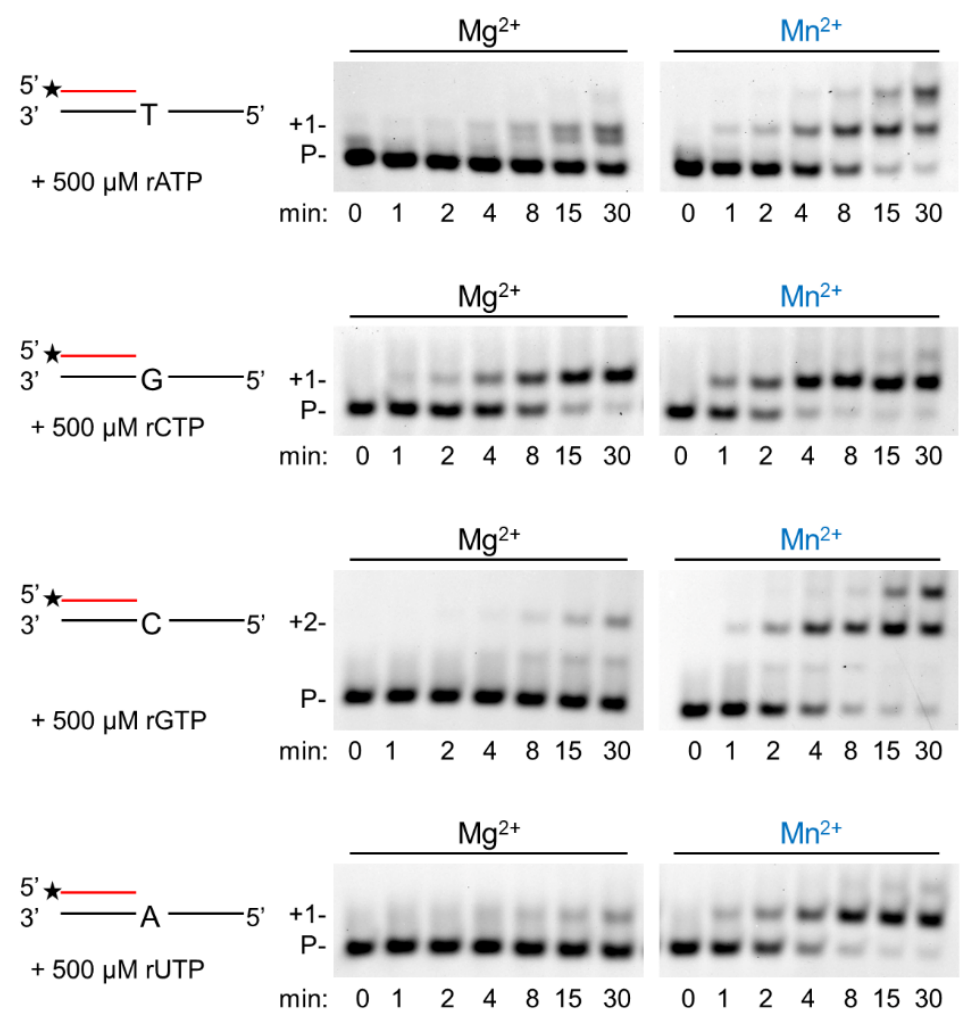

Figure 3. Manganese enhances the velocity of the polymerization reaction. Primer extension reactions were performed with $5 \mathrm{nM}$ hPoln, $20 \mathrm{nM}$ RNA/DNA, $500 \mu \mathrm{M}$ of individual rNTPs, and $4 \mathrm{mM} \mathrm{Mg}^{2+}$ or $\mathrm{Mn}^{2+}$ for the indicated times. Labels are the same as in Figure 1.

Table 1. Kinetic parameters of RNA extension with rNTPs by hPoln using $\mathrm{Mg}^{2+}$ or $\mathrm{Mn}^{2+}$ as cofactors.

\begin{tabular}{|c|c|c|c|c|c|c|c|}
\hline $\begin{array}{l}\text { Templating } \\
\text { Nucleotide }\end{array}$ & $\begin{array}{l}\text { Incoming } \\
\text { Nucleotide }\end{array}$ & Cation & $\begin{array}{c}k_{\text {cat }} \\
\left(\min ^{-1}\right)\end{array}$ & $\begin{array}{c}\mathrm{K}_{\mathrm{m}} \\
(\mu \mathrm{M})\end{array}$ & $\begin{array}{c}\mathrm{k}_{\mathrm{cat}} / \mathrm{K}_{\mathrm{m}} \\
\left(\min ^{-1} \mu \mathrm{M}^{-1}\right)\end{array}$ & $\begin{array}{c}\text { Relative } \\
\text { Efficiency }^{\text {a }}\end{array}$ & $\begin{array}{l}\text { 1/Relative } \\
\text { Efficiency }{ }^{b}\end{array}$ \\
\hline \multirow[t]{2}{*}{$\mathrm{T}$} & rATP & $\mathrm{Mn}^{2+}$ & $0.30 \pm 0.01$ & $5.9 \pm 0.7$ & $5.2 \times 10^{-2}$ & - & 1 \\
\hline & rUTP & $\mathrm{Mn}^{2+}$ & $0.048 \pm 0.002$ & $634 \pm 144$ & $7.5 \times 10^{-5}$ & - & 690 \\
\hline \multirow[t]{3}{*}{ G } & $\mathrm{rCTP}$ & $\mathrm{Mg}^{2+}$ & $0.86 \pm 0.05$ & $1427 \pm 202$ & $6.0 \times 10^{-4}$ & 1 & - \\
\hline & $\mathrm{rCTP}$ & $\mathrm{Mn}^{2+}$ & $1.27 \pm 0.04$ & $4.9 \pm 0.6$ & $2.6 \times 10^{-1}$ & 430 & 1 \\
\hline & rUTP & $\mathrm{Mn}^{2+}$ & $0.064 \pm 0.004$ & $995 \pm 226$ & $6.5 \times 10^{-5}$ & - & 3970 \\
\hline \multirow[t]{3}{*}{$\mathrm{C}$} & rGTP & $\mathrm{Mg}^{2+}$ & $0.34 \pm 0.06$ & $6260 \pm 1564$ & $5.5 \times 10^{-5}$ & 1 & - \\
\hline & rGTP & $\mathrm{Mn}^{2+}$ & $0.54 \pm 0.02$ & $7.9 \pm 0.9$ & $6.9 \times 10^{-2}$ & 1260 & 1 \\
\hline & rUTP & $\mathrm{Mn}^{2+}$ & $0.030 \pm 0.004$ & $1274 \pm 519$ & $2.4 \times 10^{-5}$ & - & 2950 \\
\hline \multirow[t]{2}{*}{ A } & rUTP & $\mathrm{Mg}^{2+}$ & $0.37 \pm 0.04$ & $4820 \pm 860$ & $7.6 \times 10^{-5}$ & 1 & - \\
\hline & rUTP & $\mathrm{Mn}^{2+}$ & $0.89 \pm 0.03$ & $15 \pm 2.0$ & $5.9 \times 10^{-2}$ & 780 & - \\
\hline \multirow[t]{2}{*}{ TT dimer } & rATP & $\mathrm{Mg}^{2+}$ & $0.54 \pm 0.04$ & $630 \pm 124$ & $8.3 \times 10^{-4}$ & 1 & - \\
\hline & rATP & $\mathrm{Mn}^{2+}$ & $0.54 \pm 0.02$ & $3.6 \pm 0.6$ & $1.5 \times 10^{-1}$ & 180 & - \\
\hline \multirow[t]{2}{*}{ 8-oxoG } & rCTP & $\mathrm{Mg}^{2+}$ & $0.11 \pm 0.01$ & $590 \pm 123$ & $1.8 \times 10^{-4}$ & 1 & - \\
\hline & $\mathrm{rCTP}$ & $\mathrm{Mn}^{2+}$ & $0.18 \pm 0.01$ & $4.0 \pm 0.5$ & $4.6 \times 10^{-2}$ & 260 & - \\
\hline
\end{tabular}

${ }^{a}$ Relative efficiency was calculated using the following equation: $\mathrm{f}_{\mathrm{rel}}=\left(\mathrm{k}_{\mathrm{cat}} / \mathrm{K}_{\mathrm{m}}\right)_{\mathrm{Mn} 2+} /\left(\mathrm{k}_{\mathrm{cat}} / \mathrm{K}_{\mathrm{m}}\right)_{\mathrm{Mg} 2+} \cdot{ }^{\mathrm{b}} 1 /$ Relative efficiency was calculated using the following equation: $\mathrm{f}_{\text {rel }}{ }^{-1}=\left(\mathrm{k}_{\text {cat }} / \mathrm{K}_{\mathrm{m}}\right)_{\text {correct }} /\left(\mathrm{k}_{\text {cat }} / \mathrm{K}_{\mathrm{m}}\right)_{\text {incorrect }}$. $\mathrm{k}_{\text {cat }}$ and $\mathrm{K}_{\mathrm{m}}$ values were calculated using data from at least three independent experiments. 

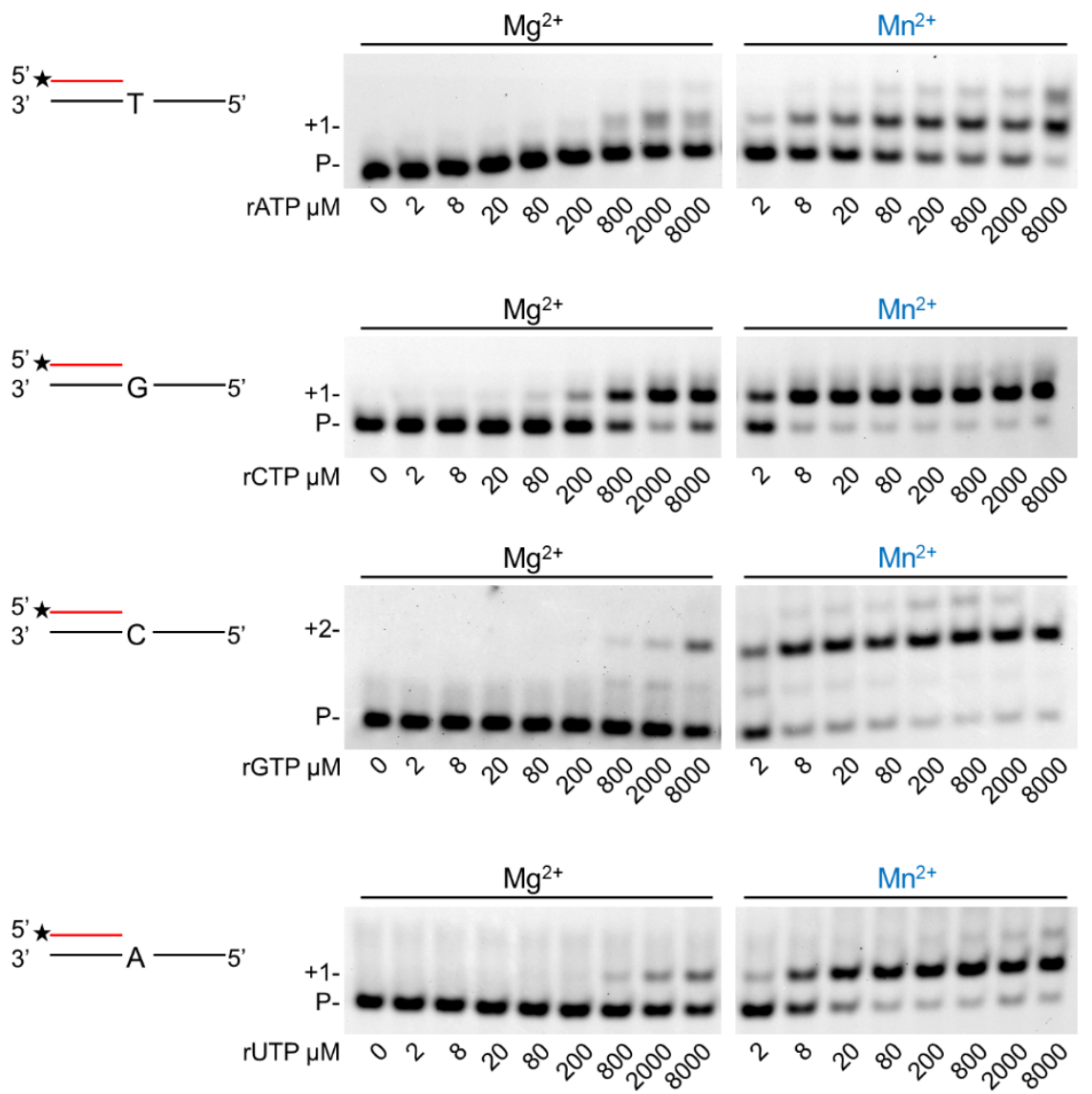

Figure 4. Manganese enhances hPol $\eta$ 's affinity to ribonucleotides. Reactions were performed using $1 \mathrm{nM}$ enzyme, $20 \mathrm{nM}$ RNA/DNA, $4 \mathrm{mM} \mathrm{Mg}^{2+}$ or $\mathrm{Mn}^{2+}$, and various concentrations of individual rNTPs as indicated. Reaction time was $45 \mathrm{~min}$. Labels are the same as in Figure 1.

\subsection{Fidelity of RNA Extension Using Manganese}

Generally, $\mathrm{Mn}^{2+}$ is regarded as a mutagenic metal cofactor that severely reduces the fidelity of DNA polymerases. Therefore, we tested the misinsertion ability of hPoln during DNA and RNA synthesis with $\mathrm{Mg}^{2+}$ and with $\mathrm{Mn}^{2+}$. Indeed, during DNA synthesis $\mathrm{Mn}^{2+}$ reduced the base selectivity of the polymerase, leading to misinsertion of all three incorrect dNMPs beside the correct one, whereas $\mathrm{Mg}^{2+}$ supported the insertion only of the correct incoming dNMP under the conditions of the reactions (Figure 5A). In sharp contrast, during RNA extension, hPoln inserted only the correct incoming rNMP, both with $\mathrm{Mg}^{2+}$ and $\mathrm{Mn}^{2+}$ (Figure 5B). Significant incorporation of the incorrect rNMPs could not be observed even after extra-long, up to $2 \mathrm{~h}$, incubation time using $\mathrm{Mn}^{2+}$ (Figure 5C). Still, UMP was misinserted with the highest efficiency, making it possible to determine the kinetic parameters. In Table 1, we compared the efficiency of correct rNMP insertion to UMP misinsertion opposite $T, G$, and $C$ in the template. As the data show, the highest difference was opposite template $\mathrm{G}$, where the correct rCMP was $\sim 4000$ times more efficiently inserted than UMP, and the lowest, 700-fold, was detected on template T. Altogether, these results demonstrated that $\mathrm{Mn}^{2+}$ did not decrease the fidelity of hPoln during RNA synthesis. 
A

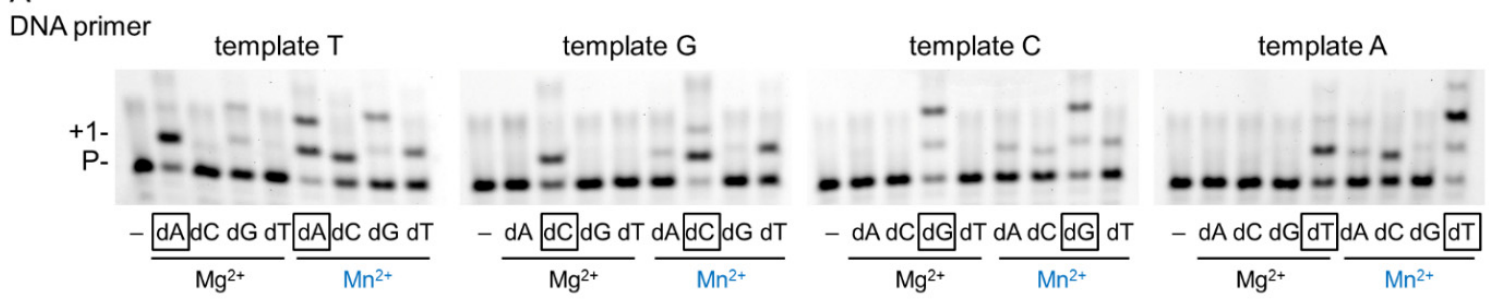

B

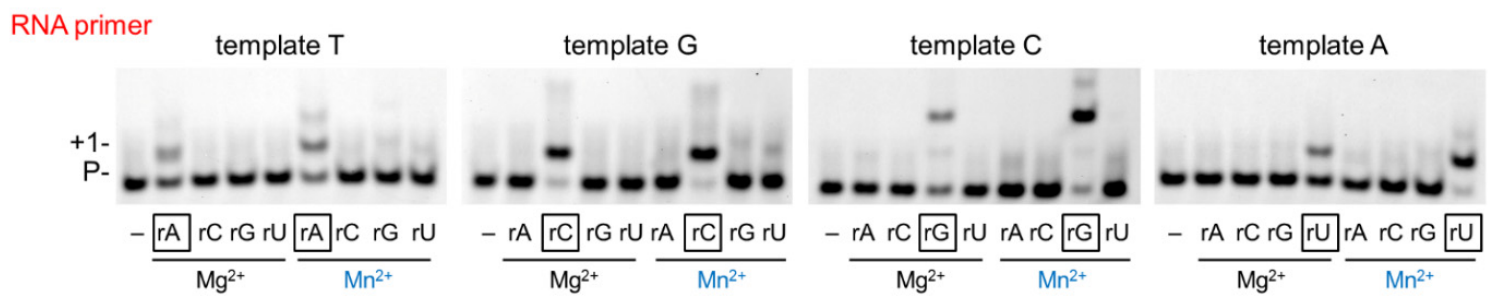

C

RNA primer $\mathrm{Mn}^{2+}$

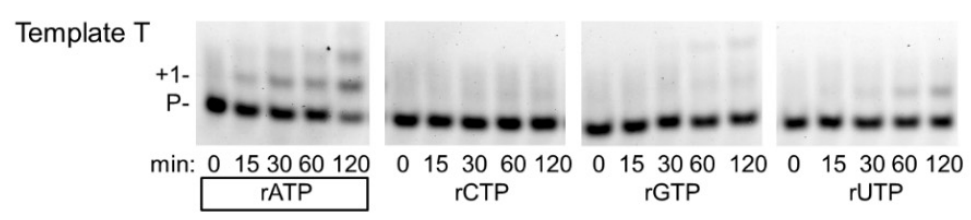

Template G

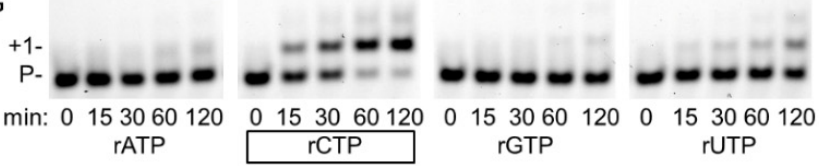

Template C

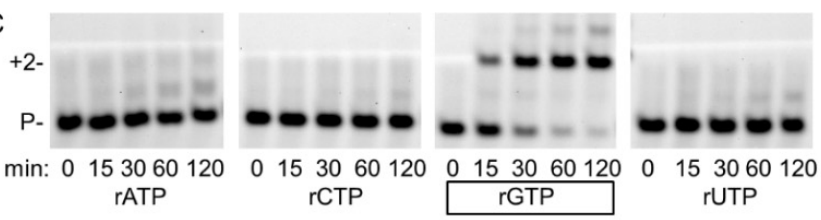

Template A

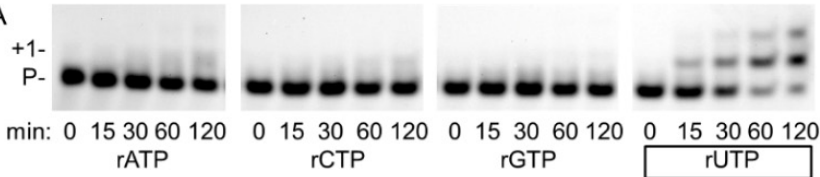

Figure 5. Fidelity of hPoln in the presence of magnesium or manganese. (A) To examine the fidelity of DNA synthesis, reactions were run with $3 \mathrm{nM}$ hPoln, $20 \mathrm{nM}$ DNA/DNA, $100 \mu \mathrm{M}$ individual $\mathrm{dNTP}$, and $4 \mathrm{mM} \mathrm{Mg}^{2+}$ or $\mathrm{Mn}^{2+}$, as indicated, for $1 \mathrm{~min}$. The first templating nucleotide is shown above each panel and the correct incoming nucleotides are framed below the pictures. (B) RNA synthesis reactions were performed as in (A) except using $20 \mathrm{nM}$ RNA/DNA and $2000 \mu \mathrm{M}$ rNTP for $15 \mathrm{~min}$. (C) Time course reactions were performed with $1 \mathrm{nM}$ hPoln, $20 \mathrm{nM}$ RNA/DNA, $4000 \mu \mathrm{M}$ of individual rNTPs, and $4 \mathrm{mM}$ Mn for the indicated times.

\subsection{DNA Damage Bypass during RNA Synthesis in the Presence of Manganese}

As hPol $\eta$ is a translesion synthesis polymerase, we investigated the effect of $\mathrm{Mg}^{2+}$ and $\mathrm{Mn}^{2+}$ on its DNA damage bypass ability during RNA extension opposite its two cognate DNA lesions, 8-oxoG and TT dimer. Like on undamaged templates, the velocity of insertion opposite 8-oxoG was almost the same using either $\mathrm{Mg}^{2+}$ or $\mathrm{Mn}^{2+}$ (Figure 6A and Table 1). Though the reaction was faster with $\mathrm{Mn}^{2+}$, the difference was less than two-fold. Likewise, near-equal velocities were observed on a TT dimer-containing template (Figure 6E). In contrast, there was a more than a hundred-fold increase in the affinity of hPol $\eta$ to rNTPs in the presence of $\mathrm{Mn}^{2+}$ using a TT dimer or an 8-oxoG containing template resulting 
in an overall $\sim 200$-fold increase in efficiency (Figure $6 \mathrm{~B}, \mathrm{~F}$ ). These data indicated that the damage bypass ability of hPoln significantly improved in the presence of $\mathrm{Mn}^{2+}$. Though the efficiency of the enzyme was lower opposite 8-oxoG than opposite undamaged G, it was almost three times better opposite the TT dimer than on undamaged $\mathrm{T}\left(1.5 \times 10^{-1}\right.$ versus $5.2 \times 10^{-2}$ ). Next, we investigated the effect of the metal cations on the base preference of hPoln during lesion bypass. As Figure 6C,D show, $\mathrm{Mn}^{2+}$ did not significantly alter the selectivity of the enzyme opposite 8-oxoG, since a significant insertion of rAMP and only minor rGMP and UMP insertions were observed besides the correct rCMP, using either metal ions. Surprisingly, however, considerably lower fidelity could be detected opposite a TT dimer with $\mathrm{Mn}^{2+}$, as evidenced by the strong misinsertion of UMP and the weak misinsertion of rCMP and rGMP besides the correct rAMP, whereas only the correct insertion of rAMP could be detected using $\mathrm{Mg}^{2+}$ (Figure 6G,H).

A
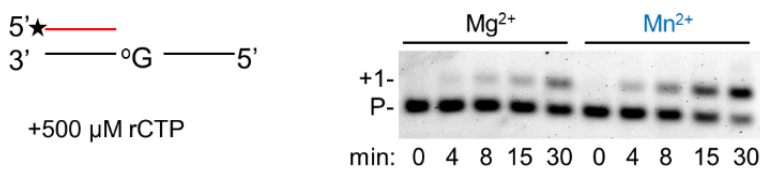

B

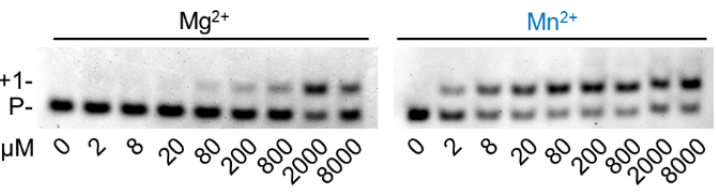

C
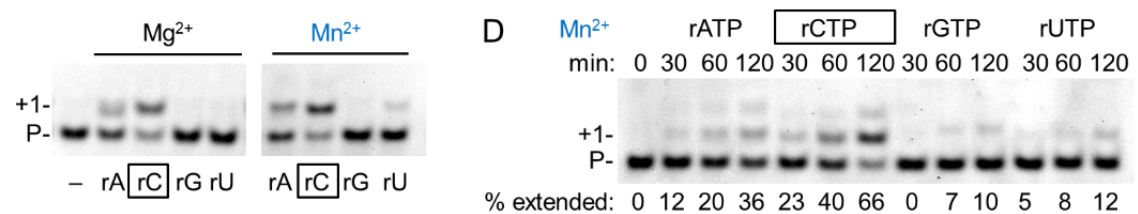

E
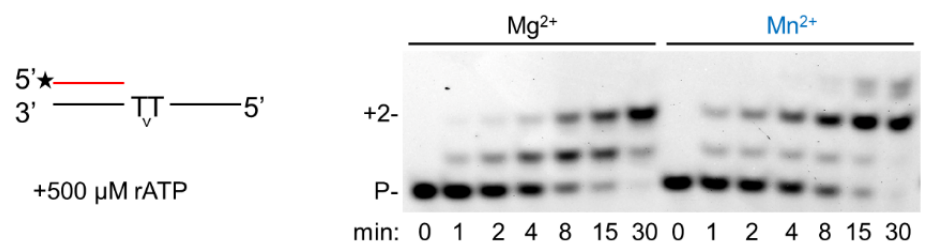

$\mathrm{F}$
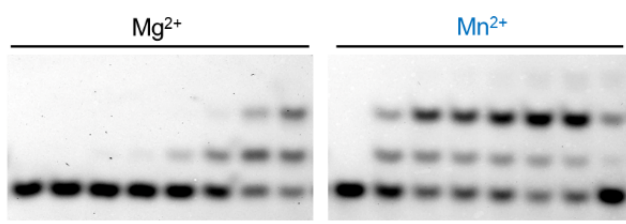

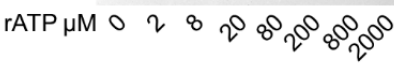
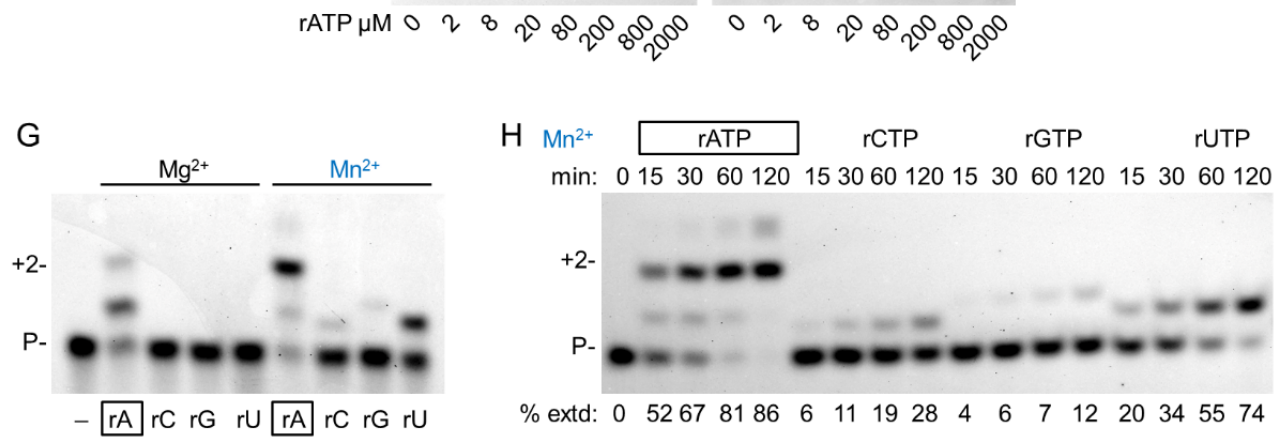

Figure 6. DNA damage bypass by hPoln during RNA synthesis using magnesium or manganese. (A-D) Bypass of 8-oxoG: (A) To check the velocity of bypass, $2 \mathrm{nM} \mathrm{hPoln} \mathrm{was} \mathrm{incubated} \mathrm{with}$ $8 \mathrm{nM}$ RNA/DNA and $500 \mu \mathrm{M}$ of rCTP for the indicated times. The asterisk indicates a fluorescent label. 
(B) The affinity of hPoln to rCTP during bypass was tested using $1 \mathrm{nM}$ enzyme and $8 \mathrm{nM}$ RNA/DNA for $45 \mathrm{~min}$ with various concentrations of $\mathrm{rCTP}$ as indicated below each lane. (C) The fidelity of oxo-G bypass was examined using $8 \mathrm{nM}$ RNA/DNA, $500 \mu \mathrm{M}$ rNTP, and either $3 \mathrm{nM}$ hPoln for $45 \mathrm{~min}$ (left panel) or $2 \mathrm{nM}$ hPoln for $30 \mathrm{~min}$ (right panel). (D) A time course of misincorporation in the presence of manganese was performed with $0.8 \mathrm{nM}$ hPoln, $8 \mathrm{nM}$ RNA/DNA, and $4000 \mu \mathrm{M}$ of individual rNTPs for the times indicated above each lane. In $(\mathbf{C}, \mathbf{D})$, the percentages of extended primers are shown below each lane. The correct incoming rCTP is boxed. (E-H) Bypass of TT dimer. (E) Bypass was assayed with $4 \mathrm{nM}$ hPol $\eta, 16 \mathrm{nM}$ RNA/DNA, and $500 \mu \mathrm{M}$ rATP for the indicated times. (F) Reactions contained $1 \mathrm{nM}$ enzyme, $16 \mathrm{nM}$ RNA/DNA, and various concentrations of rATP, as indicated below each lane. Incubation time was $45 \mathrm{~min}(\mathrm{G})$ Reactions were performed using $16 \mathrm{nM}$ RNA/DNA, $500 \mu \mathrm{M}$ individual rNTPs, and $3 \mathrm{nM}$ hPol $\eta$ for $15 \mathrm{~min}$. (H) A time course of misincorporation in the presence of manganese was run with $1 \mathrm{nM}$ hPol $\eta, 16 \mathrm{nM}$ RNA/DNA, and $500 \mu \mathrm{M}$ of individual rNTPs for the times indicated above each lane. In $(\mathbf{E}-\mathbf{H})$ labels are the same as on $(\mathbf{A}-\mathbf{D})$.

\section{Discussion}

In this study, we investigated the metal ion dependence of the RNA synthetic activity of hPoln. We aimed to examine whether it improves by replacing the metal cofactor $\mathrm{Mg}^{2+}$ with other metals. The idea stemmed from our previous results showing that the weak RNA extension ability of yPol $\eta$ dramatically increased when $\mathrm{Mn}^{2+}$ was applied instead of $\mathrm{Mg}^{2+}$ as a metal cofactor [29]. $\mathrm{Mn}^{2+}$ was previously shown to increase the activity of several other DNA polymerases like Pols $\beta, \imath, \lambda, \mu$, and PrimPol [30-34]. Moreover, for Pol $\lambda$ and Primpol, $\mathrm{Mn}^{2+}$ is considered an adequate metal cofactor. $\mathrm{Mn}^{2+}$ positively influenced both the efficiency and fidelity of these enzymes, regardless of whether dNTPs or rNTPs were used in the reactions. In sharp contrast, $\mathrm{Mn}^{2+}$ selectively improved the RNA synthetic activity of yPoln, whereas it compromised the DNA synthetic activity of the polymerase.

Here we report, that similarly to its yeast counterpart, the RNA extension ability of $\mathrm{hPol} \eta$ is greatly and selectively improved in the presence of $\mathrm{Mn}^{2+}$. Moreover, the inability of other metal ions to support the reaction suggests that $\mathrm{Mn}^{2+}$ is the adequate metal cofactor of hPol $\eta$ during RNA synthesis. Though $\mathrm{Mg}^{2+}$ also facilitates RNA extension to a small extent, it is very inefficient in agreement with published results [26]. Our experiments reveal that $\mathrm{Mn}^{2+}$ does not considerably alter the binding affinity of hPol $\eta$ toward RNA/DNA hybrid chains or increase the velocity of the reaction, but it confers a two order of magnitude higher affinity to hPoln towards rNTPs. Importantly, in contrast to DNA synthesis, during RNA synthesis the base selectivity of hPoln is not corrupted by $\mathrm{Mn}^{2+}$, which is generally considered as one of the most mutagenic metals, further confirming its specific requirement for RNA extension. Moreover, $\mathrm{Mn}^{2+}$ improves RNA synthesis by hPoln opposite an 8-oxoG and a TT dimer as well.

Comparing our previous and present results obtained with yeast and human Poln, respectively, we can conclude that the activities of both polymerases are similarly affected by $\mathrm{Mn}^{2+}$ : the DNA synthetic activities of the enzymes are compromised by the severely diminished base selectivity conferred by $\mathrm{Mn}^{2+}$, whereas their weak RNA synthetic activities are greatly improved without affecting the fidelity. Importantly, their bypass abilities across TT dimer and 8-oxG are also significantly enhanced in the presence of $\mathrm{Mn}^{2+}$. However, $\mathrm{Mn}^{2+}$ enhances the bypass activity of yPoln several thousand-fold opposite the two lesions, as opposed to the 200-fold increase observed with hPol $\eta$. Interestingly, hPol $\eta$ inserts the correct $\mathrm{rAMP}$ opposite a TT dimer even more efficiently than opposite an undamaged T in the presence of $\mathrm{Mn}^{2+}$. It suggests that TT dimer bypass is one of the main functions of $\mathrm{hPol \eta}$, even during RNA synthesis. It is noteworthy that $\mathrm{Mn}^{2+}$ decreases the base selectivity of hPol $\eta$ opposite the TT dimer, as we observed substantial UMP and weak rCMP and rGMP incorporations, in addition to the correct rAMP. It could indicate that hPoln needs other factors to maintain its fidelity during the bypass or that it is more substantial for the cell to accomplish the bypass and ensure the continuity of synthesis than to preserve the correct sequence in the RNA strand. Considering the second possibility, at least two cellular

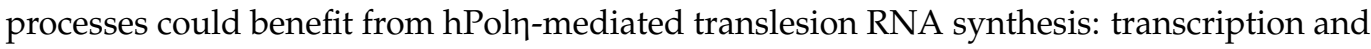


replication during Okazaki fragment synthesis. A transcriptional role of hPoln is strongly supported by our previous results indicating the involvement of yPol $\eta$ in transcription elongation. By analogy with yPoln, we propose that hPoln contributes to DNA lesion bypass during transcription through its translesion RNA synthetic activity, acquiring $\mathrm{Mn}^{2+}$ as a metal cofactor. In that case, the lowered bypass fidelity of TT dimers can mostly go undetected owing to the redundancy of the genetic code and the fact that minor structural perturbations often leave protein function unaffected. This model is supported by recent finding showing the requirement of $\mathrm{hPoln}$ for the in vivo transcriptional bypass of N2alkyl-2'-deoxyguanosine adducts [35]. Another possibility is that during the RNA primer synthesis at Okazaki fragments, hPoln could replace hPol $\alpha$ to carry out lesion bypass, as suggested by others [27]. We consider this possibility less likely, as primer synthesis can be reinitiated downstream of the lesion that could be bypassed by Pol $\eta$ through translesion DNA synthesis during the replication of the single-stranded gap. Still, even RNA primer synthesis would not be negatively affected by the lowered TT bypass fidelity of hPol $\eta$ during RNA synthesis due to the subsequent degradation of the RNA part during Okazaki fragment maturation. In conclusion, through RNA translesion synthesis, hPol $\eta$ could maintain the continuity of both processes, thus avoiding the severe consequences that stalled replication and transcription complexes can bring about.

In summary, based on our results, we suggest a role for hPoln in translesion RNA synthesis during transcription. The presented data provide additional supporting evidence to our previous model, assuming that selective metal ion binding is a new regulatory mechanism contributing to the switch between the DNA and RNA synthetic activities of some polymerases. So far, this group only includes yeast and human Pol $\eta$; therefore, more studies are needed to elucidate its relevance to other enzymes.

\section{Materials and Methods}

\subsection{Protein Purification}

Human Poln was overexpressed as N-terminal fusion with glutathione S-transferase (GST) in Saccharomyces cerevisiae BJ5464 protease deficient strain, and affinity purified on glutathione-Sepharose 4B beads (GE Healthcare, Uppsala, Sweden) using the same protocol as for yeast Poln [28]. The GST-tag was removed in the last step of the purification by incubating the beads with PreScission protease (Merck KGaA, Darmstadt, Germany). The efficiency of the purification was verified by polyacrylamide gel electrophoresis and Coomassie staining (Merck KGaA, Darmstadt, Germany), and the protein concentration was determined using a Nanodrop spectrophotometer and a gel-based assay.

\subsection{Oligonucleotides}

Sequences of DNA/DNA and RNA/DNA primer/template substrates used for the primer extension reactions have been described previously [29]. For EMSA, Og944 5' TTTTTTTTTCGAGCAACTCTTGAGGCAGGCTAGGTAGCG as a template and Og530 5' Cy3-CGCTACCTAGCCTGCCTCAAGAGTTGCTCG as DNA primer or Og531 5' Сy3CGCUACCUAGCCUGCCUCAAGAGUUGCUCG as RNA primer were annealed. Oligonucleotides used as primers contained a fluorophore indocarbocyanine (Cy3) label at the 5 -ends. Oligonucleotides were purchased from Integrated DNA Technologies, Coralville, Iowa, USA, except for the 8-oxoG-containing template, which was from Midland Certified Reagent Co., Midland, Texas, USA, and the TT dimer-containing oligonucleotide, which was from Trilink Biotechnologies, San Diego, California, USA.

\subsection{Electrophoretic Mobility Shift Assays}

Purified hPoln (from 22 to $175 \mathrm{nM}$ in 11 increments) was incubated with $10 \mathrm{nM}$ Cy3-labelled DNA/DNA or RNA/DNA primer/template substrates in buffer R (25 mM Tris/ $\mathrm{HCl} \mathrm{pH}$ 8.0, $50 \mathrm{mM} \mathrm{NaCl}, 5 \mathrm{mM} \mathrm{MgCl} 2 / \mathrm{MnCl}_{2}, 1 \mathrm{mM}$ DTT, $10 \%$ glycerol, $100 \mu \mathrm{g} / \mathrm{mL}$ BSA) for $30 \mathrm{~min}$ on ice. Samples were run on a $4 \%$ non-denaturing polyacrylamide gel in 0.5\% TB buffer ( $45 \mathrm{mM}$ Tris/ $\mathrm{HCl} \mathrm{pH}$ : 8.0) and imaged by Typhoon Trio Phosphorimager (GE 
Healthcare, Little Chalfont, Buckinghamshire, UK). The bound fraction was calculated using ImageQuant TL software (version 7.0, GE Healthcare, Little Chalfont, Buckinghamshire, $\mathrm{UK}$ ) and the binding constants (binding maximum, $\mathrm{B}_{\max }$; Hill coefficient, $\mathrm{n}$; binding affinity, $\mathrm{K}_{\mathrm{d}}$; and the standard deviation of each) were calculated using the SigmaPlot program (version 12.5 Systat Software, San Jose, CA, USA) by fitting to the Hill equation $\mathrm{Y}=\mathrm{B}_{\max } \times \mathrm{X}^{\mathrm{n}} /\left(\mathrm{K}_{\mathrm{d}}^{\mathrm{n}}+\mathrm{X}^{\mathrm{n}}\right)$

\subsection{Primer Extension Assays}

Standard primer extension reactions $(5 \mu \mathrm{L})$ contained $25 \mathrm{mM}$ Tris $/ \mathrm{HCl} \mathrm{pH} 7.7,10 \%$ glycerol, $100 \mu \mathrm{g} / \mathrm{mL}$ bovine serum albumin, 0.05\% Tween-20, $2 \mathrm{mM}$ DTT (added fresh), and the specified divalent cation as chloride salt, as well as substrate and enzyme as described in the figure legends. Reactions were initiated by the addition of the cation at the indicated concentrations, incubated at $37^{\circ} \mathrm{C}$, and quenched by the addition of $15 \mu \mathrm{L}$ loading buffer containing 95\% formamide, 18-mM EDTA, 0.025\% SDS, $0.025 \%$ bromophenol blue, and $0.025 \%$ xylene cyanol. The reaction products were resolved on $10-14 \%$ polyacrylamide gels containing $7 \mathrm{M}$ urea and analyzed with a Typhoon TRIO Phosphorimager (GE Healthcare, Little Chalfont, Buckinghamshire, UK).

\subsection{Determination of Steady-State Kinetic Parameters}

Primer extension reactions were performed as described above with the following modifications. On undamaged templates, $1 \mathrm{nM}$ hPoln was incubated with $20 \mathrm{nM}$ of primer/template substrate in a standard buffer containing $4 \mathrm{mM} \mathrm{MgCl} 2$ or $\mathrm{MnCl}_{2}$. Reactions were initiated by adding the corresponding single rNTP, which varied from 250 to $6000 \mu \mathrm{M}$ (final concentration), in 10 steps for $\mathrm{Mg}^{2+}$ or from 2 to $250 \mu \mathrm{M}$ in 10 steps for $\mathrm{Mn}^{2+}$. Incubation at $37^{\circ} \mathrm{C}$ proceeded for $35 \mathrm{~min}, 10 \mathrm{~min}, 50 \mathrm{~min}$, or $45 \mathrm{~min}$ in cases of $\mathrm{rATP}, \mathrm{rCTP}$, rGTP, or UTP, respectively, in the presence of magnesium, and $25 \mathrm{~min}, 5 \mathrm{~min}, 15 \mathrm{~min}$, or $10 \mathrm{~min}$ in cases of rATP, rCTP, rGTP, or UTP, respectively, in the presence of manganese. To quantitate the misincorporation of UTP in the presence of $\mathrm{Mn}^{2+}$, UTP was varied from 500 to $6000 \mu \mathrm{M}$ and reactions proceeded for $60 \mathrm{~min}, 60 \mathrm{~min}$, or $100 \mathrm{~min}$ in the cases of template $\mathrm{T}$, template $\mathrm{G}$, or template $\mathrm{C}$, respectively. For kinetic analysis of TT dimer bypass, $1 \mathrm{nM}$ hPol $\eta$ was incubated with $16 \mathrm{nM}$ substrate in a standard buffer. Reactions were initiated by adding rATP 200 to $3000 \mu \mathrm{M}$ in the case of $\mathrm{Mg}^{2+}$ or 1 to $120 \mu \mathrm{M}$ in the case of $\mathrm{Mn}^{2+}$ and incubated at $37^{\circ} \mathrm{C}$ for $5 \mathrm{~min}$ for both. For kinetic analysis of 8-oxo-guanine bypass, $1 \mathrm{nM}$ hPol $\eta$ was incubated with $8 \mathrm{nM}$ substrate in standard buffer. Reactions were initiated by adding rCTP 200 to $3000 \mu \mathrm{M}$ in the case of $\mathrm{Mg}^{2+}$ or 1 to $120 \mu \mathrm{M}$ in the case of $\mathrm{Mn}^{2+}$ and incubated at $37^{\circ} \mathrm{C}$ for $30 \mathrm{~min}$ or $15 \mathrm{~min}$ using $\mathrm{Mg}^{2+}$ or $\mathrm{Mn}^{2+}$, respectively.

The intensity of the gel bands corresponding to the substrate and the product was quantitated with Typhoon TRIO Phosphorimager using ImageQuant TL software, and the observed rates of nucleotide incorporation were plotted as a function of rNTP concentration. The data were fit by non-linear regression using the SigmaPlot program to the MichaelisMenten equation describing a hyperbola, $\mathrm{v}=\mathrm{V}_{\max } \times[\mathrm{rNTP}] /\left(\mathrm{K}_{\mathrm{m}}+[\mathrm{rNTP}]\right)$. The steadystate parameters $\mathrm{k}_{\mathrm{cat}}$ and $\mathrm{K}_{\mathrm{m}}$ and their standard deviations were obtained from the fit and were used to calculate the efficiency $\left(\mathrm{k}_{\mathrm{cat}} / \mathrm{K}_{\mathrm{m}}\right)$ and the relative efficiency (activation by $\mathrm{Mn}^{2+}$ versus $\left.\mathrm{Mg}^{2+}\right)$ using the formula $\mathrm{f}_{\text {rel }}=\left(\mathrm{k}_{\text {cat }} / \mathrm{K}_{\mathrm{m}}\right)_{\mathrm{Mn} 2+} /\left(\mathrm{k}_{\text {cat }} / \mathrm{K}_{\mathrm{m}}\right)_{\mathrm{Mg} 2+}$.

Author Contributions: Conceptualization, E.B. and I.U.; formal analysis, E.B. and I.U.; investigation, E.B. and I.U.; writing—original draft preparation, I.U.; writing—review and editing, E.B. and I.U.; visualization, E.B.; supervision, I.U.; funding acquisition, I.U. All authors have read and agreed to the published version of the manuscript.

Funding: This research was funded by the National Research, Development and Innovation Office (grant number GINOP-2.3.2-15-2016-00024).

Acknowledgments: We thank Aniko Bozo-Toth for technical assistance.

Conflicts of Interest: The authors declare no conflict of interest. 


\section{References}

1. Prakash, S.; Johnson, R.E.; Prakash, L. EUKARYOTIC TRANSLESION SYNTHESIS DNA POLYMERASES: Specificity of Structure and Function. Annu. Rev. Biochem. 2005, 74, 317-353. [CrossRef]

2. Vaisman, A.; Woodgate, R. Translesion DNA polymerases in eukaryotes: What makes them tick? Crit. Rev. Biochem. Mol. Biol. 2017, 52, 274-303. [CrossRef]

3. Dumstorf, C.A.; Mukhopadhyay, S.; Krishnan, E.; Haribabu, B.; McGregor, W.G. REV1 Is Implicated in the Development of Carcinogen-Induced Lung Cancer. Mol. Cancer Res. 2009, 7, 247-254. [CrossRef] [PubMed]

4. Pan, Q.; Wang, L.; Liu, Y.; Li, M.; Zhang, Y.; Peng, W.; Deng, T.; Peng, M.-L.; Jiang, J.-Q.; Tang, J.; et al. Knockdown of POLQ interferes the development and progression of hepatocellular carcinoma through regulating cell proliferation, apoptosis and migration. Cancer Cell Int. 2021, 21, 482. [CrossRef] [PubMed]

5. Ohkumo, T.; Kondo, Y.; Yokoi, M.; Tsukamoto, T.; Yamada, A.; Sugimoto, T.; Kanao, R.; Higashi, Y.; Kondoh, H.; Tatematsu, M.; et al. UV-B Radiation Induces Epithelial Tumors in Mice Lacking DNA Polymerase $\eta$ and Mesenchymal Tumors in Mice Deficient for DNA Polymerase ı. Mol. Cell. Biol. 2006, 26, 7696-7706. [CrossRef] [PubMed]

6. Lee, G.-H.; Matsushita, H. Genetic linkage between Politoa deficiency and increased susceptibility to lung tumors in mice. Cancer Sci. 2005, 96, 256-259. [CrossRef]

7. Lin, Q.; Clark, A.B.; McCulloch, S.D.; Yuan, T.; Bronson, R.T.; Kunkel, T.A.; Kucherlapati, R. Increased Susceptibility to UV-Induced Skin Carcinogenesis in Polymerase $\eta$-deficient Mice. Cancer Res. 2006, 66, 87-94. [CrossRef] [PubMed]

8. Yoon, J.-H.; McArthur, M.J.; Park, J.; Basu, D.; Wakamiya, M.; Prakash, L.; Prakash, S. Error-Prone Replication through UV Lesions by DNA Polymerase $\theta$ Protects against Skin Cancers. Cell 2019, 176, 1295-1309.e15. [CrossRef]

9. Johnson, R.E.; Kondratick, C.M.; Prakash, S.; Prakash, L. hRAD30 Mutations in the Variant Form of Xeroderma Pigmentosum. Science 1999, 285, 263-265. [CrossRef]

10. Masutani, C.; Kusumoto, R.; Yamada, A.; Dohmae, N.; Yokoi, M.; Yuasa, M.; Araki, M.; Iwai, S.; Takio, K.; Hanaoka, F. The XPV (xeroderma pigmentosum variant) gene encodes human DNA polymerase $\eta$. Nature 1999, 399, 700-704. [CrossRef]

11. Haracska, L.; Yu, S.-L.; Johnson, R.E.; Prakash, L.; Prakash, S. Efficient and accurate replication in the presence of 7,8-dihydro-8oxoguanine by DNA polymerase $\eta$. Nat. Genet. 2000, 25, 458-461. [CrossRef]

12. Haracska, L.; Prakash, S.; Prakash, L. Replication past O 6 -Methylguanine by Yeast and Human DNA Polymerase $\eta$. Mol. Cell. Biol. 2000, 20, 8001-8007. [CrossRef]

13. Haracska, L.; Washington, T.; Prakash, S.; Prakash, L. Inefficient Bypass of an Abasic Site by DNA Polymerase $\eta$. J. Biol. Chem. 2001, 276, 6861-6866. [CrossRef]

14. Patra, A.; Zhang, Q.; Lei, L.; Su, Y.; Egli, M.; Guengerich, F.P. Structural and Kinetic Analysis of Nucleoside Triphosphate Incorporation Opposite an Abasic Site by Human Translesion DNA Polymerase $\eta$. J. Biol. Chem. 2015, 290, 8028-8038. [CrossRef] [PubMed]

15. Vaisman, A.; Masutani, C.; Hanaoka, F.; Chaney, S.G. Efficient Translesion Replication Past Oxaliplatin and Cisplatin GpG Adducts by Human DNA Polymerase $\eta$. Biochemistry 2000, 39, 4575-4580. [CrossRef] [PubMed]

16. Albertella, M.R.; Green, C.; Lehmann, A.R.; O'Connor, M.J. A Role for Polymerase $\eta$ in the Cellular Tolerance to Cisplatin-Induced Damage. Cancer Res. 2005, 65, 9799-9806. [CrossRef]

17. McElhinny, S.A.N.; Watts, B.E.; Kumar, D.; Watt, D.L.; Lundström, E.-B.; Burgers, P.M.J.; Johansson, E.; Chabes, A.; Kunkel, T.A. Abundant ribonucleotide incorporation into DNA by yeast replicative polymerases. Proc. Natl. Acad. Sci. USA 2010, 107, 4949-4954. [CrossRef]

18. Su, Y.; Egli, M.; Guengerich, F.P. Mechanism of Ribonucleotide Incorporation by Human DNA Polymerase $\eta$. J. Biol. Chem. 2016, 291, 3747-3756. [CrossRef]

19. Vaisman, A.; Woodgate, R. Ribonucleotide discrimination by translesion synthesis DNA polymerases. Crit. Rev. Biochem. Mol. Biol. 2018, 53, 382-402. [CrossRef]

20. Mentegari, E.; Crespan, E.; Bavagnoli, L.; Kissova, M.; Bertoletti, F.; Sabbioneda, S.; Imhof, R.; Sturla, S.J.; Nilforoushan, A.; Hübscher, U.; et al. Ribonucleotide incorporation by human DNA polymerase $\eta$ impacts translesion synthesis and RNase H2 activity. Nucleic Acids Res. 2016, 45, 2600-2614. [CrossRef] [PubMed]

21. Eder, P.; Walder, R.; Walder, J.A. Substrate specificity of human RNase H1 and its role in excision repair of ribose residues misincorporated in DNA. Biochimie 1993, 75, 123-126. [CrossRef]

22. Rydberg, B.; Game, J. Excision of misincorporated ribonucleotides in DNA by RNase H (type 2) and FEN-1 in cell-free extracts. Proc. Natl. Acad. Sci. USA 2002, 99, 16654-16659. [CrossRef]

23. Sparks, J.L.; Chon, H.; Cerritelli, S.M.; Kunkel, T.A.; Johansson, E.; Crouch, R.J.; Burgers, P.M. RNase H2-Initiated Ribonucleotide Excision Repair. Mol. Cell 2012, 47, 980-986. [CrossRef]

24. Crow, Y.J.; Leitch, A.; Hayward, B.E.; Garner, A.; Parmar, R.; Griffith, E.; Ali, M.; Semple, C.; Aicardi, J.; Babul-Hirji, R.; et al. Mutations in genes encoding ribonuclease $\mathrm{H} 2$ subunits cause Aicardi-Goutières syndrome and mimic congenital viral brain infection. Nat. Genet. 2006, 38, 910-916. [CrossRef]

25. Günther, C.; Kind, B.; Reijns, M.; Berndt, N.; Bueno, M.M.; Wolf, C.; Tüngler, V.; Chara, O.; Lee, Y.A.; Hübner, N.; et al. Defective removal of ribonucleotides from DNA promotes systemic autoimmunity. J. Clin. Investig. 2014, 125, 413-424. [CrossRef]

26. Su, Y.; Egli, M.; Guengerich, F.P. Human DNA polymerase $\eta$ accommodates RNA for strand extension. J. Biol. Chem. 2017, 292, 18044-18051. [CrossRef] 
27. Su, Y.; Ghodke, P.P.; Egli, M.; Li, L.; Wang, Y.; Guengerich, F.P. Human DNA polymerase $\eta$ has reverse transcriptase activity in cellular environments. J. Biol. Chem. 2019, 294, 6073-6081. [CrossRef]

28. Gali, V.K.; Balint, E.; Serbyn, N.; Frittmann, O.; Stutz, F.; Unk, I. Translesion synthesis DNA polymerase $\eta$ exhibits a specific RNA extension activity and a transcription-associated function. Sci. Rep. 2017, 7, 13055. [CrossRef]

29. Balint, E.; Unk, I. Selective Metal Ion Utilization Contributes to the Transformation of the Activity of Yeast Polymerase $\eta$ from DNA Polymerization toward RNA Polymerization. Int. J. Mol. Sci. 2020, 21, 8248. [CrossRef]

30. Pelletier, H.; Sawaya, M.R.; Wolfle, W.; Wilson, S.H.; Kraut, J. A Structural Basis for Metal Ion Mutagenicity and Nucleotide Selectivity in Human DNA Polymerase $\beta$. Biochemistry 1996, 35, 12762-12777. [CrossRef]

31. Blanca, G.; Shevelev, I.; Ramadan, K.; Villani, G.; Spadari, S.; Hübscher, U.; Maga, G. Human DNA Polymerase $\lambda$ Diverged in Evolution from DNA Polymerase $\beta$ toward Specific Mn++ Dependence: A Kinetic and Thermodynamic Study. Biochemistry 2003, 42, 7467-7476. [CrossRef]

32. Martin, M.J.; Garcia-Ortiz, M.V.; Esteban, V.; Blanco, L. Ribonucleotides and manganese ions improve non-homologous end joining by human Pol $\mu$. Nucleic Acids Res. 2012, 41, 2428-2436. [CrossRef]

33. Frank, E.G.; Woodgate, R. Increased Catalytic Activity and Altered Fidelity of Human DNA Polymerase $\iota$ in the Presence of Manganese. J. Biol. Chem. 2007, 282, 24689-24696. [CrossRef]

34. Zafar, M.K.; Ketkar, A.; Lodeiro, M.F.; Cameron, C.E.; Eoff, R.L. Kinetic Analysis of Human PrimPol DNA Polymerase Activity Reveals a Generally Error-Prone Enzyme Capable of Accurately Bypassing 7,8-Dihydro-8-oxo-2'-deoxyguanosine. Biochemistry 2014, 53, 6584-6594. [CrossRef]

35. Tan, Y.; Guo, S.; Wu, J.; Du, H.; Li, L.; You, C.; Wang, Y. DNA Polymerase $\eta$ Promotes the Transcriptional Bypass of N2-Alkyl-2'deoxyguanosine Adducts in Human Cells. J. Am. Chem. Soc. 2021, 143, 16197-16205. [CrossRef] 